\title{
L.S. Semenova
}

\section{IMPORTANCE OF STUDYING I.V. LESHKO-POPEL'S ACTIVITIES FOR THE MORAL EDUCATION OF MEDICAL STUDENTS}

SE «Dnipropetrovsk medical academy of Health Ministry of Ukraine»

Department of Social Medicine, Organization and Health Administration

Dzerzhinsky str., 9, Dnipro, 49044, Ukraine

ГУ «Днепропетровская медииинская академия МЗ Украинь»

кафедра сочиильной медицины, организащии и управления здравохранения

ул. Дзержинского, 9, Днепр, 49044, Украина

Key words: Leshko-Popel, humanism, selflessness, moral education

Ключевые слова: Лешко-Попель, гуманизм, самоотверженность, нравственность, воспитание

Abstract. Importance of studying I.V. Leshko-Popel's activities for the medical students' moral education. Semenova L.S. This article is about I. V. Leshko-Popel who was a well-known doctor of Yeukaterinoslav in the late XIX century. He was called "the friend of the poor", "People's doctor", "outstanding doctor-man". He was always and everywhere ready to help selflessly the patient where poor people were waiting for him. Author of this article proposec methods to study I. V. Leshko-Popel's activities for moral education of medical students.

Реферат. Важность изучения деятельности И.В. Ляшко-Попеля для нравственного воспитания студентов-медиков. Семенова Л.С. Эта статья об И.В. Лешко-Попеле, который был хорошо известныл врачом Екатеринослава в коние ХІХ столетия. Его называли «другом бедных», «народнылм доктором», «выдающимся врачом-человеком». Он всегда был готов бескорыстно помочь пациенту, везде, где ждали его бедные люди. Автор статьи предлагает методы изучения деятельности И.В. Лешко-Попеля для нравственного воспитания студентов-медиков.

The main part of general education of medical students is moral one. The best method of moral education is the studying of activities of well-known historical persons who have become the examples of the best human characteristics.

An example of selfless service to the people was the work of a doctor and humanist of Yekate- rinoslav, Ivan Leshco-Popel, called "the friend of the poor", " People's doctor", "the outstanding doctorman". He is name was well-known in Russia in the late XIX and early XX century. Life and humanitarian aspirations of I.V. Leshco-Popel serve as an example for the moral education of the young generations of doctors, based on the best traditions from the past.

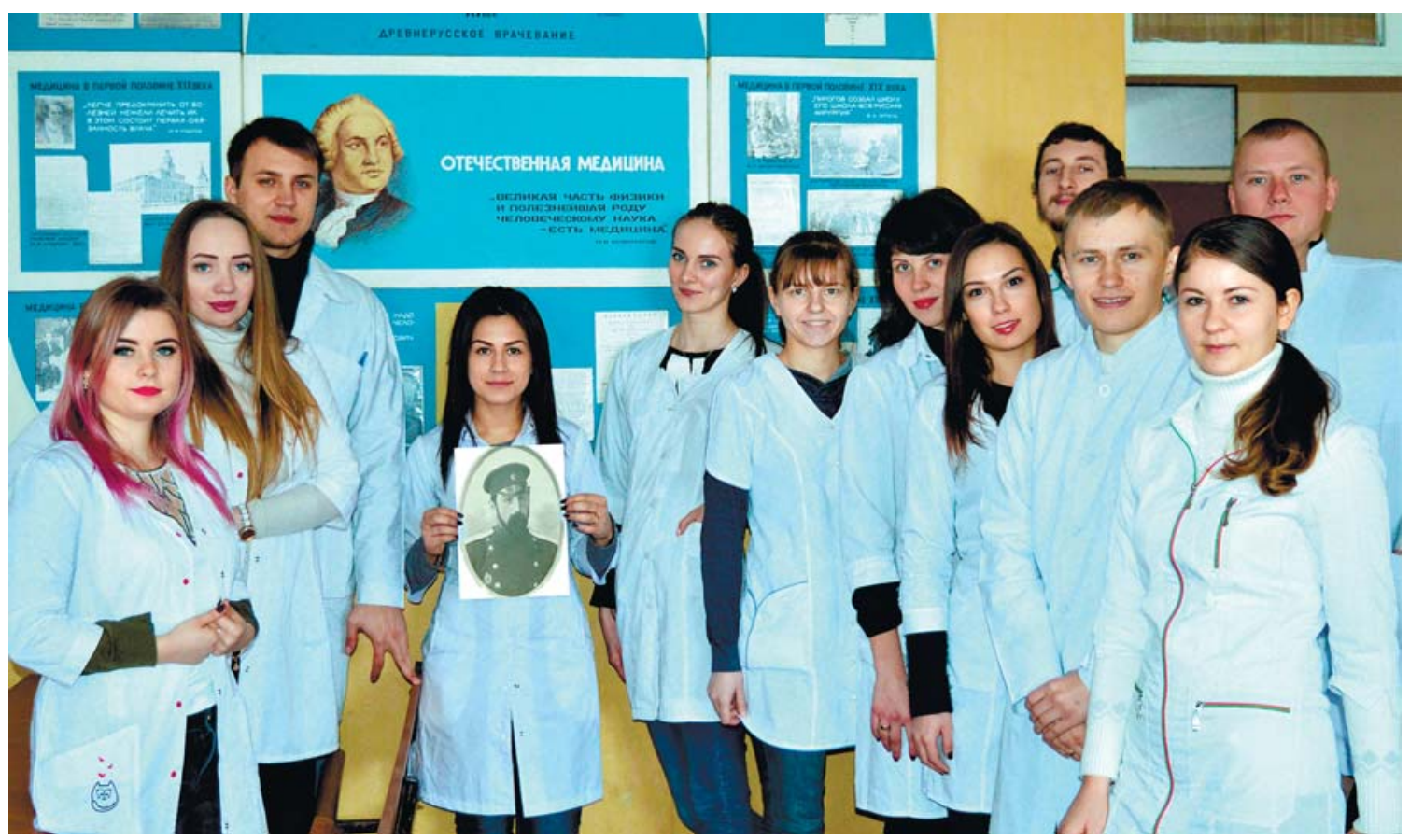

Medical students' conference about I.V. Leshko-Popel's activities 


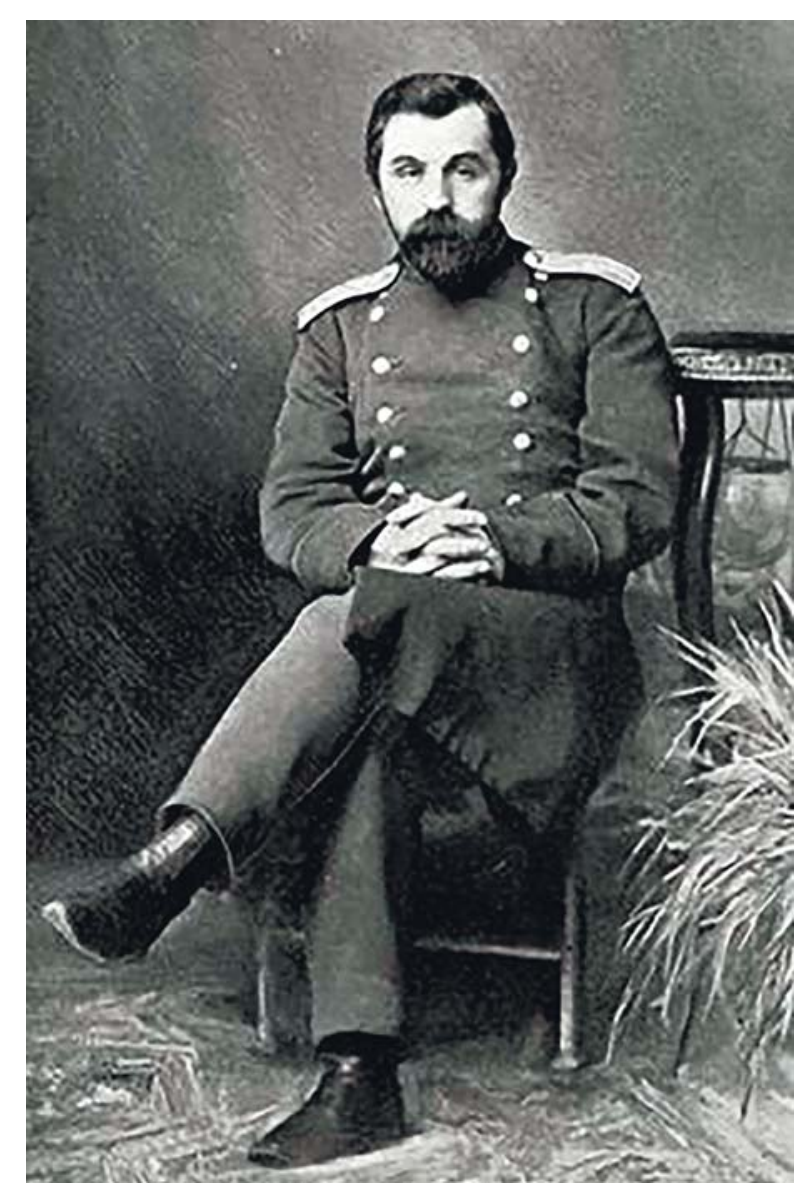

Ivan Leshco-Popel

The man of great soul, with a deep understanding of the medical duty Ivan Leshco-Popel differed from many of his colleagues, with his special sensitivity and responsiveness. Day and night people were knocking at his door, and he was always ready, "to help the patient and to walk to the opposite end of the city on foot, on Kaidak or Amur, where people were waiting for him as a hope as a healer"[3]. At that time, his contemporaries, evaluating the activities of I.V. Leshco-Popel, compared them with the activities of the outstanding Russian physician-humanist F.P. Gaas, A.G. Avchinnikov wrote: "The memory of people similar to Gaas, must be supported like a lamp ... no doubt, the physician Ivan Leshco-Popel" belonged to such bright personalities [1].The same idea is also confirmed by A.A. Osipov: "... in front of you emerges the figure of the doctor, who would have willingly given a hand and who would have been attracted into its embrace by the unforgettable Fyodor Petrovich Gaas"[3]. Among the people there were legends about the miraculous doctor, about his great professional skill, that he treated patients not only with the help of potions and powders, but "with an incorruptible kindness, generosity of a great soul"'[3].
Despite the great interest, which was represented by the medical and social activities of I.V. LeshcoPopel, despite a high appreciation by his contemporaries, but his activity has been poorly studied. In 1904 a small book of A.G. Ovchinnikov was published with the title:"Friend of the poor", in which the merits of I.V. Leshco-Popel were vividly shown as a social activist. This book provoked numerous reviews and contemporaries considered it necessary to make this edition get into the public libraries, .. "so that the memory of the unforgettable physician and humanist will be immortal"[3]. In 1907, the book was republished in Warsaw, and in 1914 - in Yekaterinoslav. Now all of its publications are a bibliographic rarity.

The goal of this research - is to study the life and the activities of a prominent doctor and humanist. From archival materials it became known that Ivan Leshco- Popel was born on 5/ IX (old style) in 1860 in the Mogilev province Rogachev in the family of a tradesman. He received his secondary education in Mogilev gymnasium. After graduating from gymnasium course in 1879, I.V. Leshco-Popel entered the natural department of Physics and Mathematics, at St. Petersburg University at that time being the center of natural science in Russia. In the years of studying I.V. Leshco-Popel had to be engaged in tutoring. With very modest means, he always helped his comrades financially[2].

In 1883 I.V. Leshco-Popel joined the III year of the Military Medical Academy. Private lessons were shortened, all the time was dwoted to lessons. The material was extensive, students were to work hard I.V. Leshco-Popel approved this rigour. "He said: the doctor is entrusted with the most precious - a person's life, what condescensions are here! The most accurate and complete knowledge is required"[2]. As a graduate student, coming home in summer I.V. Lesco-Popiel, sought out sick people on the outskirts of the city, he was treating them and helping them. His working capacity and endurance were enormous. With an excellent balanced character, Ivan was an indispensable companion, famous for his generosity and kindness. One day, under his curatorship in the clinic, there was lying a seriously ill woman.

There was no hope for her recovery, she felt that and was very worried.

"I do not feel sorry for myself, but for my son she cried, - the boy is 9 years. What will happen to him?" The patient's woe influenced I.V. Leshco-Popel. Consoling her, he asked whether it would be easier if she knew that the boy would be taken care of. The woman replied affirmatively. Then Ivan said, "I will take your son". The next morning, he 
brought the boy to the owner of the apartment and said: "Daria Ivanovna, here is another freeloader. Accept him as you accepted me". He paid the expenses of the boy out of his own scholarship [2].

In 1886 I.V. Leshco-Popel received the title of doctor, and was appointed as a junior doctor of the 54th battalion of reserve of personnel deployed in Yekaterinoslav. The soldiers immediately fell in love with the new doctor for the tender, attentive attitude, and different from many other predecessors. "Sometimes, even some other military servitors surreptitiously came to see him in neighboring parts of barracks"[5].

I.V. Leshco-Popel settled in a small house on Tikhaya street. He provided medical care not only to the military but also to civilians.

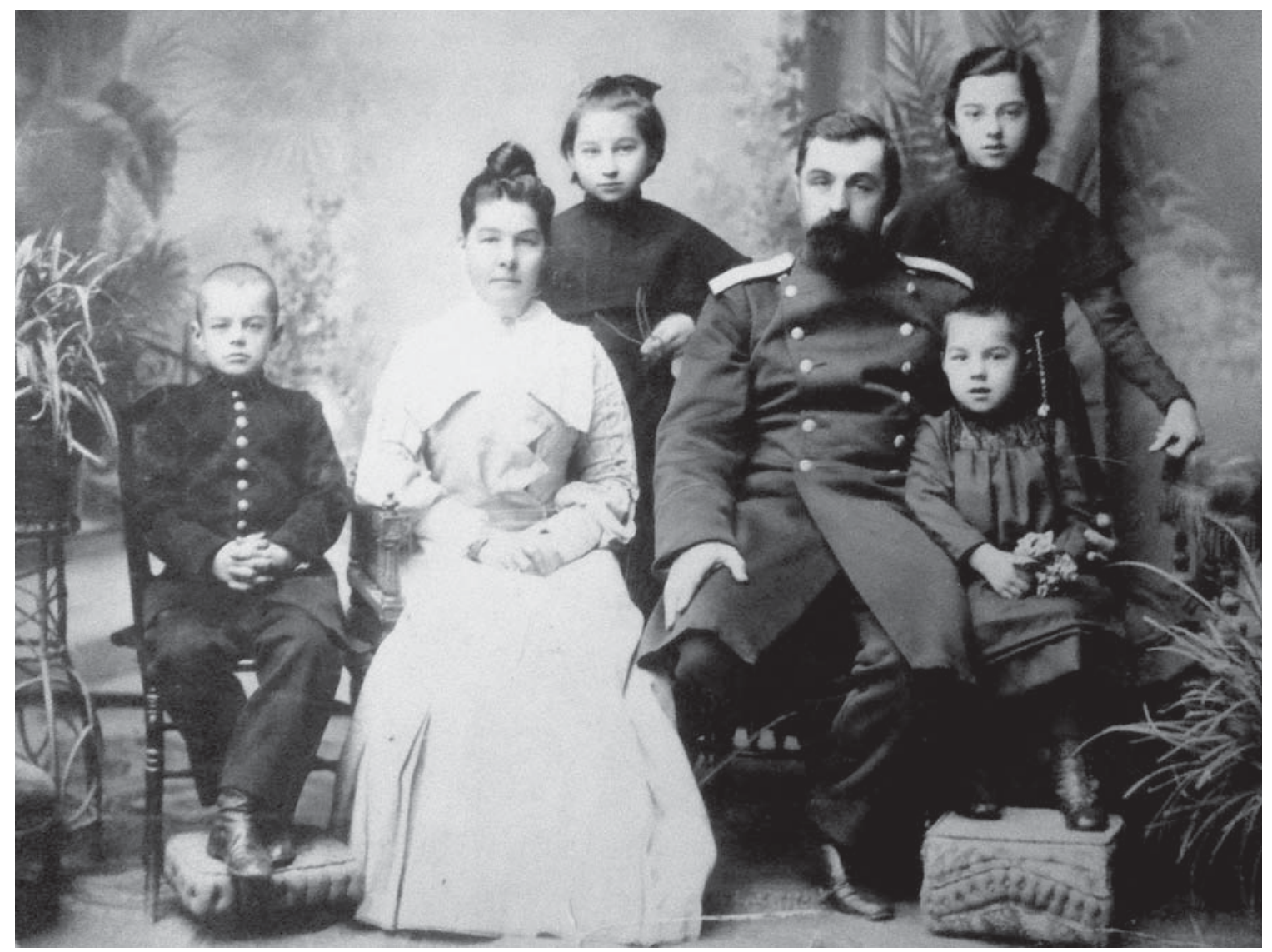

\section{I.V. Leshko-Popel's family}

In pre-revolutionary Yekaterinoslav medical care was provided badly. There were dozens of private doctors for rich people, but a working man could not pay for the doctor visit Therefore, a lot of the poor went to I.V. Leshco-Popel, who at any time was available for them. "There was no such further, abandoned corner of Yekaterinoslav, where Ivan Vasilyevich had refused to go"[5]. He was one of those doctors who truly understood their duty towards the people trying to alleviate their position. He was a doctor in the finest sense of the word, a man, whose noble spirit and high ideals could not be destroyed by the monotony of life.

Doctor Leshko-Popel treated patients for free, and ".. often he left on the table a rouble or two for medicine, prepaid for milk in the neighboring store for malnourished boy, who could only be cured by high feeding" [5].

A.G. Avchinnikov described his activity as an indefatigable fighter for human health. Frequently, the doctor came back home from the patient's house and he was always ready "to go at night to the place where the patient was lying unconscious"[3]. One night, in the rainy weather, Ivan Vasilyevich with his companion came to see a patient, who lived in the suburbs of old Yekaterinoslav. The patient needed ice. But being a poor man, he could not get any ice in the middle of the night. "Go with me!" Ivan Vasilyevich said to his companion and they both returned to the doctor's house. There, turning on the flashlight and picking up the bucket, Ivan Vasilyevich went down to his ice storage room and 
chopped some ice, then he made his way back to the patient, together with the poor man"[1]. Coming back from the long trips, tired, he immediately went to visit his patients.

$\mathrm{He}$ was one of the best pediatricians in Yekaterinoslav of that time, was called in by rich people, but his patients were more important for him than money, received from rich people.

Since 1888, I.V. Leshko-Popel was a member of Yekaterinoslav medical society that was established on 21/IX/1874 and when the branch of St. Petersburg mutual aid society appeared in the town, he was continuously one of the three judges of honor. Yekaterinoslav medical society played a major role in the development of medicine, organized special committees to study tuberculosis, malaria and cholera, propagated hygienic knowledge, applied for improvement of medical care for poor population. When Ivan Vasilyevich learnt that the medical community had taken a decision to establish free-ofcharge night doctor's duties in the town, he was one of the first to participate, and always fulfilled his responsibilities of the duty doctor with utmost care. He was well aware of his necessity for the poor. I.V. Leshko-Popel treated poor patients free of charge, made notes on the prescription about selling drugs at reduced prices, and often paid his own money for drugs. When one poor lady asked Ivan Vasilyevich for medical aid, he did not charge a fee for medical advice and treatment. And when that lady went to the pharmacy to order a medicine, Ivan Vasilyevich followed her and claimed that he had forgotten to make a note on the prescription for selling a drug at a discount.

I.V. Leshko-Popel took an active part in charity, but his first priority was the human being who needed medical assistance. One citizen of Yekaterinoslav wrote that when her husband was ill, she sent for Ivan Vasilyevich; the messenger returned and reported that the doctor would arrive in a few hours, as he had to attend some important emergency meeting. But the family was surprised when Ivan Vasilyevich entered the house in full dress and said, that he only has a few minutes to spare, and he hurried to the sick man. "He examined my husband, prescribed a medicine and left. The next day Ivan Vasilyevich came to see us again without engagement and gave him free treatment" [1]. Common people loved and respected him and they called him "our doctor". He did not confine himself to treatment of mere disease; but a heartfelt word was an essential component of general treatment.

At 7 o'clock in the morning, poor patients crowded around his house, he was seeing them before departing to practice; then he returned about midnight, totally worn out, and again got down to work in the morning. This continued day after day, for years till the end.

I.V. Leshko-Popel returned to the colleagues' comments: "What else? I'm a doctor!"After spending the night at the bed of patient and coming back home in the morning, he said: "Oh, how I am satisfied! One patient was dying, but I tore him out!". He replied to the answer about his tiredness: "No problem, I slept enough today". But he was already called to another place, and so it was every day [1]. Many intellectuals looked at I.V. LeshkoPopel quizzically the friends said: "Crank!", "Eccentric!", "How can you work like that?" For all time of his work in Yekaterinoslav Ivan Vasil'evich had never used a deserved vacation. When he was advised to have a rest, referring that others rest, he answered: "But others, when they leave, pass their patients to their colleagues, but no one take my patients, they don't need anyone". In any weather, at any time of the day or night, healthy or sick I.V. Leshko-Popel granted requests with out inquiring the name, status of patient who needed help. For almost 17 years, he had been working tirelessly in Yekaterinoslav in the field of traditional medicine, surrounded by the love and respect of ordinary people. Caring about others, doctor-humanist paid little attention to himself. He still continued to go to patients within 2 days after he had become seriously ill. After he had rescued a critically ill child, he was seriously infected. When illness forced him to bed, he said with an embarrassed smile: "It's good to lie down... will have a rest, otherwise I was going to do it for a long time, but I couldn't at all" [1].

The Newspapers of Yekaterinoslav reported: "The well-known doctor in the city had fallen ill seriously". Many of his patients from the poorest part of the urban population in poor clothes, in pitiful tatters besieged apartment, where he lived, coping about his health. At the same day Ivan Vasilyevich died. The journalist mr. Osipov described people's sorrow in the newspaper "Pridneprovsk region: "Quiet street. It is dark. Light of lanterns flashed from afar, tram buzzing hardly heard. Life does not come here, but it would be powerless... Near small house, enclosed with fence from the street, a crowd of people". People crowded at the door of the poor apartment of a man who "did not collect gold treasures because he was too rich spiritually". At many factories that day "workers did not have a dinner and served civil funeral"[3]. Yekaterinoslav had never seen such a crowd united... in such a sincere deep feeling"[1]. A lot of troubles fell on police alarmed by enormous crowd of people. But popularity of I.V. Leshko-Popel was so great 
that local authorities didn't dare to forbid mass procession. Many articles appeared in newspapers and journals, that described the mood of Yekaterinoslav inhabitants. They cherished as a shrine for memory about kind doctor and his deeds in their hearts. The writer B.I. Livner wrote a poetic legend about wonderful doctor I.V. Leshko-Popel "Devoted love" (1903). "People's doctor" was buried on 15/12 in Novodevichiy cloister of Yekaterinoslav.

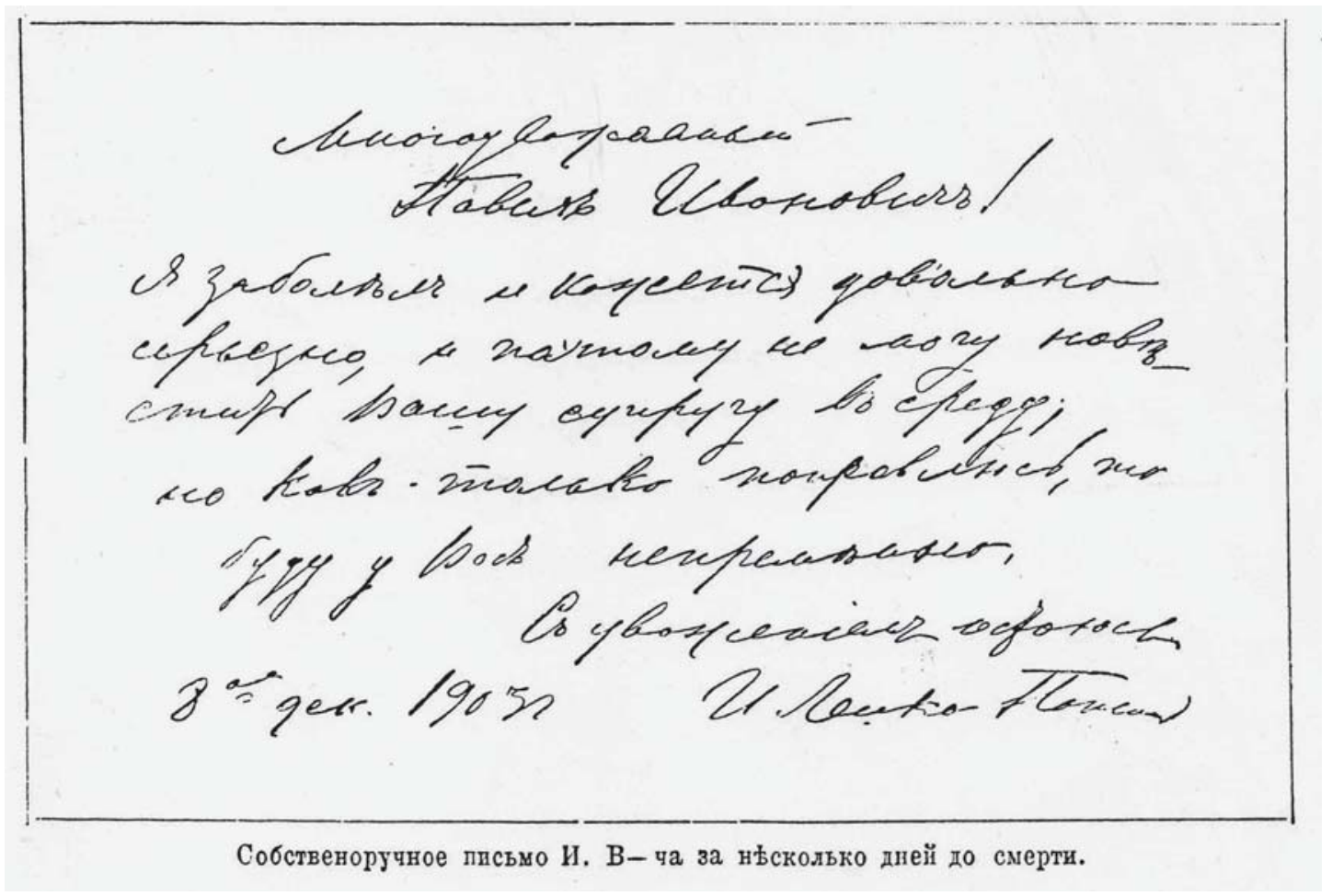

The letter that was written by I.V. Leshko-Popel several days before his death

A question about perpetuation the memory of Ivan Vasil'evich has been raised in 19/12/1903 by Yekaterinoslav Duma. It was decided to arrange in the city outskirts a free hospital of his name for the poor and to establish 2 beds in the city hospital that were given for indigent men and woman of different nationalities. Then Medical communities of Yekaterinoslav initiated a petition on conferring the name I.V. Leshko-Popel to the street of the city poor outskirts, where the doctor-humanist spent his life and worked. The petition was satisfied. Now it is I.V. Leshco-Popel street.

I.V. Leshko-Popel lived a short but bright life, that was given to people without the rest. P.Y. Kovalev pointed out that it was "a continuous feat"[3].
A.F. Koni in the artistic-biographical sketch "F.P. Gaaz" rightly wrote: "Great people who have died, continue to act as an example like if they were alive"[4]. These words are fully referred to the doctor-humanist Ivan Vasilyevich Leshko-Popel.

History of medicine is the science that widens medical students' outlook, promotes the development of their general culture and moral education. That is why we propose the medical students to prepare historical reports and presentations. We organize conference, discussions about I.V. LeshkoPopel and another outstanding historical figures. Our practice demonstrates positive results to improve medical students' moral education.

\section{REFERENCES}

1. Avchinnikov AY. [Friend of the poor]. Yekaterinoslav. Izd. Yakovleva, 1904;28. Russian

2. Avchinnikov AY. [Doctor Leshko-Popel]. Warsaw. Izd. Timinsky, 1907;28. Russian

3. Bajan TA. [Doctor humanist and progressive public worker I.V. Leshko-Popel]. Soviet Public Health. 1975;8:77-80. Russian.
4. Koni AF. [Composition]. Moskva. Juridicheskaya literature, 1968;5:480. Russian.

5. Shatrov M. [City on tree hills]. Dnepropetrovsk. Promin, 1968;191. Ukraine. 


\section{СПИСОК ЛИТЕРАТУРЫ}

1. Авчинников А.Г. Друг бедных / А.Г. Авчинников. - Екатеринослав: Печатня С.П. Яковлева, 1904. - 28 с.

2. Авчинников А.Г. Доктор Лешко-Попель / А.Г. Авчинников. - Варшава: - Изд-во Тиминского, 1907. -7 c.

3. Бажан Т.Л. Врач гуманист и прогрессивный общественный деятель И.В. Ляшко-Попель
Т.Л. Бажан, Л.Е. Мороз // Сов. здравоохранение. 1975. - № 8 - С. 77-80.

4. Кони А.Ф. Собрание сочинений. Т. 5. / А.Ф. Кони. - Москва: Юридическая литература, 1968. - 480 с.

5. Шатров М. Город на трёх холмах. - Днепропетровск: Проминь, 1969. - 191 с.
Ю.В. Козлова,

М.А. Довгаль,

В.В. Колдунов,

Г.А. Клопоцький,

О.С. Худяков,

С.I. Хмель,

В.М. Бібікова,

Н.С. Трясак,

O.B. Aнісімова
ІСТОРИЧНИЙ НАРИС

КАФЕДРИ ПАТОЛОГІЧНОЇ ФІЗІОЛОГІЇ ДНІПРОПЕТРОВСЬКОЇ МЕДИЧНОЇ АКАДЕМІЇ

ДЗ «Дніпропетровська медична академія МОЗ України»

кафедра патологічної фізіології

(в.о. зав. - д. мед. н., проф. В.В. Колдунов)

вул. Дзержсинсккого, 9, Дніпро, 49044, Україна

SE «Dnipropetrovsk medical academy of Health Ministry of Ukraine»

Department of Pathophysiology

Dzerzhinsky str., 9, Dnipro, 49044, Ukraine

e-mail:jyliftuna@ukr.net

Ключові слова: історія, кафедра, патологічна фізіологія

Key words: history, department, pathological physiology

Реферат. Исторический очерк кафедры патологической физиологии Днепропетровской медицинской академии. Козлова Ю.В., Довгаль М.А., Колдунов В.В., Силкина Ю.В., Клопоцкий Г.А., Худяков А.Е., Хмель С.И., Бибикова В.Н., Трясак Н.С., Анисимова О.В. В статье представлены исторические сведения о развитии кафедры патологической физиологии Днепропетровской медицинской академии, о заведуюших и их вкладе в развитие кафедры от момента основания (1918 год) до настоямего времени (2016 год). Описаньл направления научных исследований, наиболее значимые достижения, отмечены изменения в материальном и методическом обеспечении педагогического прочесса. 